\title{
慢性維持透析患者における心房細動カテーテルアブ レーション治療
}

小堀敦志 ${ }^{1}$ 高橋 淳 $^{2}$ 桑原大志 $^{2}$ 滝川正晃 $^{2}$ 古川 裕 $^{1}$

慢性維持透析患者における心房細動 (AF) 発症率は高いものの, 抗不整脈薬の使 用制限などから透析管理が困難な場合が多い, 一方で, 透析患者における AFアブ レーションについての詳細な報告は少ない。自験例の透析患者群(23名)での AF アブレーション治療の現状は, 複数回セッション(平均 $1.46 \pm 0.5$ 回) 後の洞調律 維持率は $47.7 \%$ であり, 条件を合わせた非透析患者群 (46名)の成績 (治療回数平 均 $1.20 \pm 0.5$ 回)の $75.6 \%$ と比較して低い傾向であつた $(p=0.07)$. 両群の患者 背景を比較したところ, カテーテルの抵抗值が透析患者群では低值で, 通電中の抵 抗值低下率の低さが多変量解析で有意であつた．また，イリゲーションカテーテル を使用した透析患者群の初回セッション後における洞調律維持率は $75 \%$ で, 非イ リゲーションカテーテル使用群での $29.5 \%$ に比較し改善傾向にあり, 今後の治療 成績改善が期待される.

(心電図, $2012 ; 32: 333 \sim 339$ )

\section{I 。はじめに}

慢性維持透析患者は, 高血圧症や動脈硬化, 弁膜 症などの基礎疾患をもつことが多く，さらに透析に よる循環血漿量や電解質の変化などから心負荷を認 めるため, 心房細動 $(\mathrm{AF})$ の発生頻度が一般よりも 高いといわれている ${ }^{1)}$. $\mathrm{AF}$ の発症率は維持透析の

\begin{tabular}{|ll|}
\hline Keywords & ・心房細動 \\
& ・カテーテルアブレーション \\
& ・血液透析 \\
\hline
\end{tabular}

1 神戸市立医療センター中央市民病院循環器内科 （～650-0047 兵庫県神戸市中央区港島南町 2-1-1） 2 横須賀共済病院循環器センター内科
期間とともに増加し, 血行動態の不安定化や抗凝固 療法の導入などによる透析管理への影響も指摘され ている ${ }^{2)}$. また, 透析患者における $\mathrm{AF}$ 治療では, 薬物排泄経路や血行動態への影響から抗不整脈薬の 選択肢が制限され，良好な管理が困難となる場合が 多いことも問題である.

近年, 抗不整脈薬抵抗性 $\mathrm{AF}$ に対する有効な治療 法として広く行われるようになってきているカテー テルアブレーションの治療成績は, 腎機能低下に影 響を受けると報告され, 腎機能低下の進行に伴い治 療の困難性が増していることから, 腎機能破綻前の 早期アブレーション治療が重要視されるようになっ てきた ${ }^{3)}$. 一方で, 末期腎不全状態の慢性維持透析

Catheter Ablation for Atrial Fibrillation in Patients with Chronic Hemodialysis

Atsushi Kobori, Atsushi Takahashi, Taishi Kuwahara, Masateru Takigawa, Yutaka Furukawa 
表 1 対象 1 : 透析患者群 (HD群) と非透析患者群(Control群)の臨床背景

\begin{tabular}{|c|c|c|c|c|}
\hline & & $\begin{array}{l}\mathrm{HD} \text { 群 } \\
\mathrm{n}=23\end{array}$ & $\begin{array}{c}\text { Control群 } \\
n=46\end{array}$ & $\mathrm{p}$ 值 \\
\hline \multicolumn{2}{|c|}{ 心房細動の種類：発作性 / 持続性 } & $21 / 2$ & $37 / 9$ & n.s. \\
\hline \multicolumn{2}{|l|}{ 年齢(歳) } & 62.7 & 64.9 & n.s. \\
\hline \multicolumn{2}{|l|}{ 性別：男性／女性 } & $13 / 10$ & $25 / 21$ & n.s. \\
\hline \multicolumn{2}{|l|}{ 左房径 (mm) } & $42.1 \pm 5$ & $41.6 \pm 7$ & n.s. \\
\hline \multicolumn{2}{|l|}{ 罹病期間(月) } & $33.3 \pm 32$ & $42.1 \pm 53$ & n.s. \\
\hline \multicolumn{2}{|l|}{ 無効抗不整脈薬数 } & 1.4 & 1.7 & n.s. \\
\hline \multirow[t]{5}{*}{ 基礎心疾患 } & & $8(35 \%)$ & $13(28 \%)$ & n.s. \\
\hline & DCM & 1 & 3 & \\
\hline & VHD & 4 & 3 & \\
\hline & $\mathrm{IHD}$ & 3 & 2 & \\
\hline & $\mathrm{CHF}$ & 2 & 5 & \\
\hline BMI & & 22.0 & 22.9 & n.s. \\
\hline
\end{tabular}

Control 群 : 心房細動アブレーション治療を受けた非透析症例コホートより, 年齢・

性別・左房径・心房細動の種類を一致させた症例を選択.

患者における AFアブレーションについて検討した 報告はほとんどみられず, 日本透析医学会のガイド ラインにて「透析患者に対する肺静脈隔離アブレー ション治療を行うことを制限するエビデンスは存在 しない」と述べられるにとどまっている ${ }^{4)}$.した がって，AFを有する慢性維持透析患者におけるカ テーテルアブレーション治療の現状と問題点を明ら かにするために, 自験例での検討を中心に報告する.

\section{II . 透析患者における心房細動アブレーション 治療の現状}

慢性維持透析を受けている薬郕抵抗性 $\mathrm{AF}$ 患者 23 例( $\mathrm{HD}$ 群)に $\mathrm{AF}$ アブレーションを行い，その後 の洞調律維持率を追跡した ${ }^{5}$. 対照として, AFア ブレーションを行った非透析患者群より， AFの種 類・年齢・性別・左房径を一致させた 46 例を抽出 した(Control群)。

$\mathrm{AF}$ アブレーションは，X線透視ガイドに非イリ ゲーションカテーテル(主に $8 \mathrm{~mm}$ チップ)を用いた 両側拡大肺静脈隔離術を主治療として行った。通電
は, 温度制限 $55^{\circ} \mathrm{C}$, 出力制限 $35 \mathrm{~W}$ (左房後壁)もし くは $40 \mathrm{~W}$ (前壁), 最長 60 秒間で食道温度が $42^{\circ} \mathrm{C}$ 以内とした，肺静脈隔離の確立は，同側上下肺静脈 内に留置したリング状カテーテルにより, 左房一肺 静脈間の両方向性ブロックを確認した。 また必要に 応じて, 左房天井ライン, 左房後壁ライン, 僧帽弁 輪側壁-左下肺静脈ライン, 上大静脈隔離術, 左房 内除細動基質アブレーションなどを追加し，全例で 下大静脈一三尖弁輪ラインを作成した. 両群の臨床 的特徵に差異は見られなかった(表 1).

両側の肺静脈隔離は全例で成功した。隔離確立ま でに要した通電部位数は, 両側合計 (HD群：32.5 土 7 点, Control群 : $27.6 \pm 7$ 点; $\mathrm{p}<0.05)$ と左側 (HD 群 : $17.3 \pm 7$ 点, Control群 : $13.9 \pm 3$ 点 $; \mathrm{p}<0.05)$ において HD群で多かった(表 2). 最終セッション 後の $\mathrm{AF}$ 再発の回避率は, $\mathrm{HD}$ 群( $47.7 \%$, 平均 $1.43 \pm$ 0.5 回後, 平均追跡期間 $24.7 \pm 16.3$ 力月) 上り Control 群 $(75.6 \%$, 平均 $1.20 \pm 0.5$ 回後, 平均追跡期間 16.5 土16.3 カ月)で高い傾向が見られた(図 1)。再セッ ション時に行われた手技では, $\mathrm{HD}$ 群で肺静脈再隔 
表 2 初回セッション時の治療内容

\begin{tabular}{|c|c|c|c|}
\hline & $\begin{array}{l}\mathrm{HD} \text { 群 } \\
\mathrm{n}=23\end{array}$ & $\begin{array}{c}\text { Control群 } \\
n=46\end{array}$ & $\mathrm{p}$ 值 \\
\hline 全肺静脈隔離確立 & $23(100 \%)$ & $46(100 \%)$ & n.s. \\
\hline 両側肺静脈隔離に要した通電部位数 & $32.5 \pm 7$ & $27.6 \pm 7$ & $<0.05$ \\
\hline 左側肺静脈 & $17.3 \pm 7$ & $13.9 \pm 3$ & $<0.05$ \\
\hline 右側肺静脈 & $14.4 \pm 4$ & $14.2 \pm 5$ & n.s. \\
\hline 両側肺静脈隔離に要したエネルギー $\left(x 10^{3} \mathrm{~J}\right)$ & $75.1 \pm 30$ & $62.6 \pm 23$ & n.s. \\
\hline 両側肺静脈隔離に要した手技時間(分） & $76.8 \pm 44$ & $72.7 \pm 28$ & n.s. \\
\hline 両側肺静脈隔離に要した透視時間(分) & $48.0 \pm 25$ & $40.2 \pm 19$ & n.s. \\
\hline 合併症 & 心囊水貯留 1 & 0 & n.s. \\
\hline
\end{tabular}

$\mathrm{HD}$ 群で肺静脈隔離に要した通電部位数が多く難渋例が多い.

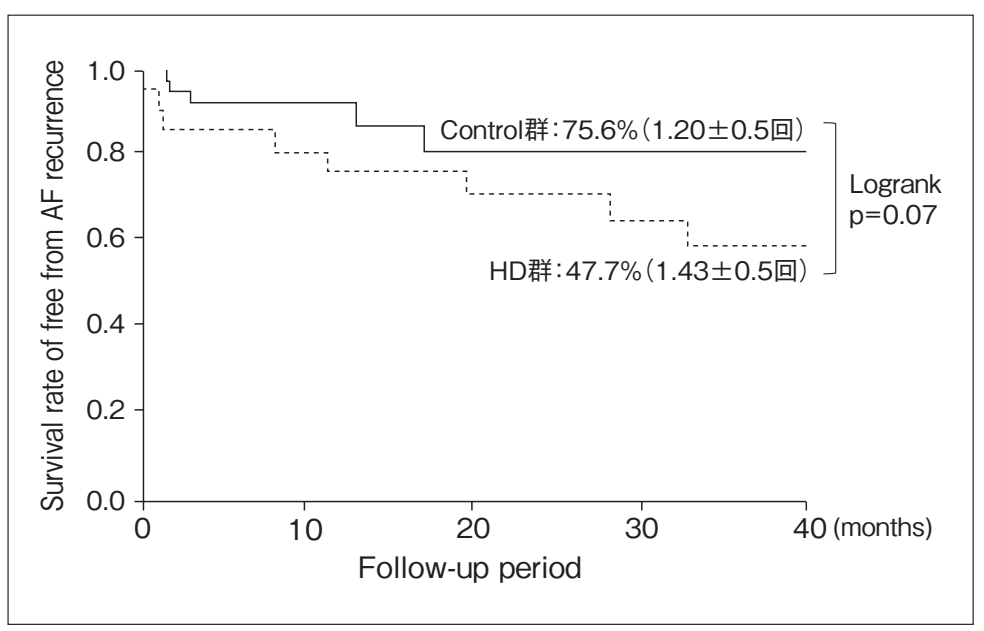

図 1

複数回セッション後の心房細動再発回避率 (Kaplan-Meir 法)

離術が多く(HD群 : 30.4\%, Control群 : 8.7\% ; p < 0.05), HD群での初回肺静脈隔離維持率が低いこと が判明した(表 3).

これらのデータは2008年以前に施行された $\mathrm{AF}$ アブレーション治療の現状であり, 様々な治療技術 の進化に伴い成績向上が見込まれる，そのため，最 近までの症例を追加し，再調查を行った，透析患者 は45例で，対照群は設けていない，初回セッショ ン後の平均追跡期間 $19.5 \pm 16.0$ カ月において, $\mathrm{AF}$ 再発回避率は $34.6 \%$ であった。 また複数回セッショ ン(平均 $1.40 \pm 0.6$ 回) 後の平均追跡期間 $13.0 \pm$ 16.0 カ月において, $\mathrm{AF}$ 再発回避率は $47.4 \%$ であっ た、いずれも以前のデータと大きく変わっていない JPN. J. ELECTROCARDIOLOGY Vol. 32 No. 42012
ことが確認された.

以上より，透析患者における AFアブレーション 治療の現状として, 初回肺静脈隔離の確立にはより 多くの通電が必要であるが, 初回セッション後の成 功維持率が低く, そのために複数回セッションが必 要な症例が多いことが示された。また, 複数回セッ ション後も約半数の症例で再発を懸念しなければな らない. ただし, これらの透析患者における再発評価 については, 透析のたびに $\mathrm{AF}$ 発症の強い要因にさ らされて再発の可能性が高い状況に置かれているこ とや, 週数回の透析受診時に頻回の脈拍管理が行われ ていることで無症候性を含めた再発がより詳細に把 握されていることにも, 影響を受けていると思われる. 
表 3 第 2 回セッション時の治療内容

\begin{tabular}{lccc}
\hline & $\begin{array}{c}\text { HD群 } \\
\mathrm{n}=23\end{array}$ & $\begin{array}{c}\text { Control群 } \\
\mathrm{n}=46\end{array}$ & $\mathrm{p}$ 值 \\
\hline 再治療症例数 & $10(43.5 \%)$ & $8(17.4 \%)$ & $<0.05$ \\
\hline 再肺静脈隔離 & $7(30.4 \%)$ & $4(8.7 \%)$ & $<0.05$ \\
上大静脈隔離術 & $2(8.7 \%)$ & $4(8.7 \%)$ & n.s. \\
左房天井ライン & $1(4.4 \%)$ & $2(4.4 \%)$ & n.s. \\
左房後壁ライン & $0(0 \%)$ & $0(0 \%)$ & n.s. \\
僧帽弁輪側壁峡部ライン & $2(8.7 \%)$ & $0(0 \%)$ & n.s. \\
Defragmentation & $0(0 \%)$ & $0(0 \%)$ & n.s. \\
心房頻拍起源 & $4(17.4 \%)$ & $3(6.5 \%)$ & n.s. \\
その他 & $1(10 \%)$ & $0(0 \%)$ & n.s. \\
\hline
\end{tabular}

$\mathrm{HD}$ 群は再治療率が高く, なかでも肺静脈隔離の再施行率が高い.

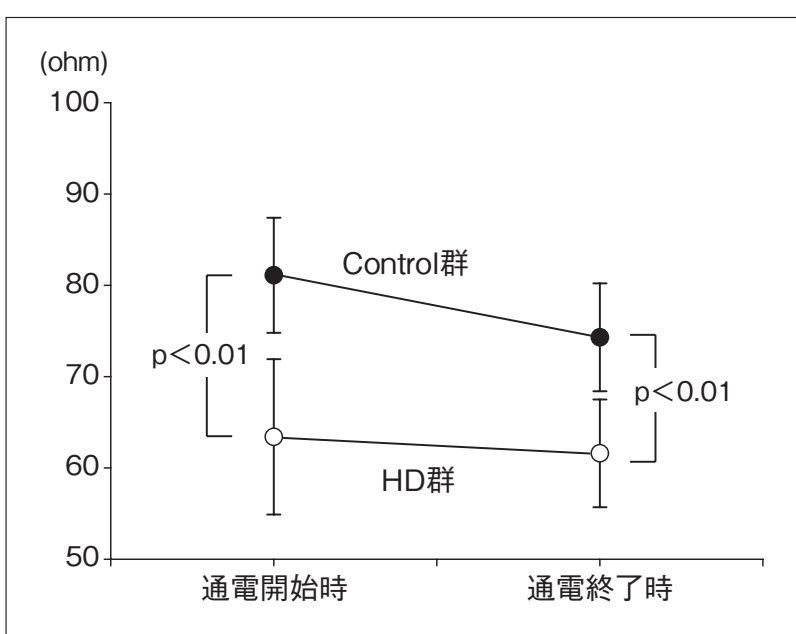

図2 左房内通電中の抵抗值の変化

$\mathrm{HD}$ 群は Control群に比し通電開始時より抵抗值が低く, 通 電中の低下も少ない.

\section{III. アブレーション治療難渋の背景解析}

次に, HD 群において肺静脈隔離を含めた $\mathrm{AF}$ ブレーションの有効性が，コントロール群に比し劣 る要因について検討した ${ }^{6)}$. 特に肺静脈隔離に要す る通電量が HD群で多いことからは, 患者側要因と しての心房筋組織変性などが疑われ，通電にかかわ る因子との関連を検討した。

両群間における通電時指標のうち, 開始時抵抗值
は HD群で低く(HD群： $81.1 \pm 1.4 \Omega$, Control群： $63.5 \pm 2.5 \Omega ; \mathrm{p}<0.01)$ と通電前後における抵抗值 低下 (HD群 : $-6.8 \pm 0.3 \Omega$, Control群 : $-3.6 \pm 0.3$ $\Omega ; \mathrm{p}<0.01$ ) は HD群で低值だった(図 2).これら を含めた両群間で有意差のあった臨床指標と，肺静 脈隔離に要した通電部位数との相関を単変量解析し た。通電回数は, 通電開始時の抵抗值が低い, 通電 前後の抵抗值低下が少ない, 血清尿素窒素值が高 い，血清クレアチニン值が高い，血清 $\mathrm{K}^{+}$值が高い ことに相関性が認められた(表 $4 A)$ ）さらに，その 4項目にて多変量解析を行ったところ，通電回数は 通電前後の抵抗值低下が少ないことにのみ相関を示 した(表 4B).

AFアブレーション治療の成否には，心房筋の十 分な焼灼巣形成が大きくかかわっており，それらの 貫壁性と連続性に依存していることはいうまでもな い.しかし，その組織性状によっては通電効果が十 分に得られない場合があり，透析患者では間質の線 維化や石灰化, 心筋細胞の粗雑化などの組織変性が 存在すると考えられる. これらの変化は, 局所抵抗 值低下と通電中の抵抗值低下率の減少に関連してい る可能性が考えられた。 
表 4 肺静脈隔離に要する通電部位数との相関関係

A. 単変量解析

\begin{tabular}{lcc}
\hline & $\mathrm{r}$ & $\mathrm{p}$ 值 \\
\hline Impedance at the beginning & -0.62 & $<0.001$ \\
Reduction of the impedance & -0.68 & $<0.001$ \\
$\mathrm{BUN}$ & 0.45 & $=0.01$ \\
$\mathrm{Cre}$ & 0.60 & $<0.001$ \\
$\mathrm{Na}$ & -0.27 & n.s. \\
$\mathrm{K}$ & 0.44 & $=0.01$ \\
\hline
\end{tabular}

B. 多变量解析

\begin{tabular}{lcc}
\hline & $\mathrm{R}$ & $\mathrm{p}$ 值 \\
\hline Impedance at the beginning & 0.05 & $\mathrm{n} . \mathrm{s}$. \\
Reduction of the impedance & 7.07 & $<0.01$ \\
$\mathrm{BUN}$ & 5.39 & 0.05 \\
$\mathrm{Cre}$ & 3.99 & n.s. \\
$\mathrm{K}$ & 2.36 & n.s. \\
\hline
\end{tabular}

$\mathrm{A}$ ：単変量解析では，血清 $\mathrm{Na}$ 值以外に相関を認めた.

$\mathrm{B}$ : 多変量解析では, 通電中の抵抗値低下との相関を認めた.

BUN : 血清尿素窒素値, Cre : 血清クレアチニン值, $\mathrm{K}$ ：血清 $\mathrm{K}^{+}$值

\section{IV . 治療効率の改善に向けて}

通電中の抵抗值低下は発生する熱量に関連するた め，十分に低下しないと貫壁性の焼灼巣が形成され ない可能性が高くなる。透析患者における肺静脈隔 離の難渋と再発率の低下を期し，まずわれわれは $8 \mathrm{~mm}$ チップカテーテルから $4 \mathrm{~mm}$ チップカテーテ ルに変更することで，抵抗值低下が得られるととも に, 通電効率が上昇し, 治療効果が改善されるか否 かについて検証した。しかし， $4 \mathrm{~mm}$ チップカテー テルでは温度制限により十分な出力が得られないこ とが多く，断念せざるをえなかった．

欧米からずいぶん遅れたが，ようやく2010年か ら我が国でもイリゲーションカテーテルが使用可能 となった。これにより温度制限による出力不足が回 避され，治療成績の改善が期待されている。 そこ で，いまだ症例数は少ないながらも治療効果の改善
につき検証を行った。

$\mathrm{AF}$ アブレーションを受けた透析患者を，非イリ ゲーションカテーテルを使用した 35 例 (Non-IR 群) と, イリゲーションカテーテルを使用した 10 例 (IR 群)に分けて， $\mathrm{AF}$ 抑制率を比較した。 $\mathrm{AF}$ の種類, 性別，年齢，罹病期間，無効薬剂数，基礎心疾患， 左房径などの臨床背景は両群間で同等であった (表 5). 初回セッション後の $\mathrm{AF}$ 再発の回避率は, Non-IR 群 (29.5\%，平均追跡期間 $14.3 \pm 17.2$ 力月)に 比し, IR群 (75\%, 平均追跡期間 $9.9 \pm 6.9$ 力月)で 高い傾向が見られた(図 3). 少症例数であること, 追跡期間が短期間であることから有意差はないもの の, イリゲーションカテーテルでの治療成績改善が 期待されると思われた。ただし，イリゲーションカ テーテルでは灌流液の水分負荷があるため, 利尿の ない透析患者では非イリゲーションカテーテル使用 時よりも輸液過剩が著明に増加することから, 長時 
表 5 対象 2 : 透析患者におけるカテーテル種別による臨床背景

\begin{tabular}{lccc}
\hline & $\begin{array}{c}\text { Non-IR群 } \\
\mathrm{n}=35\end{array}$ & $\begin{array}{c}\text { IR群 } \\
\mathrm{n}=10\end{array}$ & $\mathrm{p}$ 值 \\
\hline 心房細動の種類 : 発作性 / 持続性 & $31 / 4$ & $8 / 2$ & n.s. \\
年齢(歳) & 60.7 & 60.3 & n.s. \\
性別 : 男性 / 女性 & $24 / 11$ & $7 / 3$ & n.s. \\
罹病期間 (月) & $39.3 \pm 35.6$ & $34.0 \pm 15.6$ & n.s. \\
無効薬剂数 & $1.6 \pm 1.6$ & $1.6 \pm 1.3$ & n.s. \\
基礎心疾患 & $45.7 \%(16)$ & $40 \%(4)$ & n.s. \\
左房径 (mm) & $43.2 \pm 5.2$ & $40.0 \pm 3.6$ & n.s. \\
\hline
\end{tabular}

Non-IR 群： $8 \mathrm{~mm}$ または $4 \mathrm{~mm}$ チップカテーテルを使用した症例

IR 群 : イリゲーションカテーテルを使用した症例

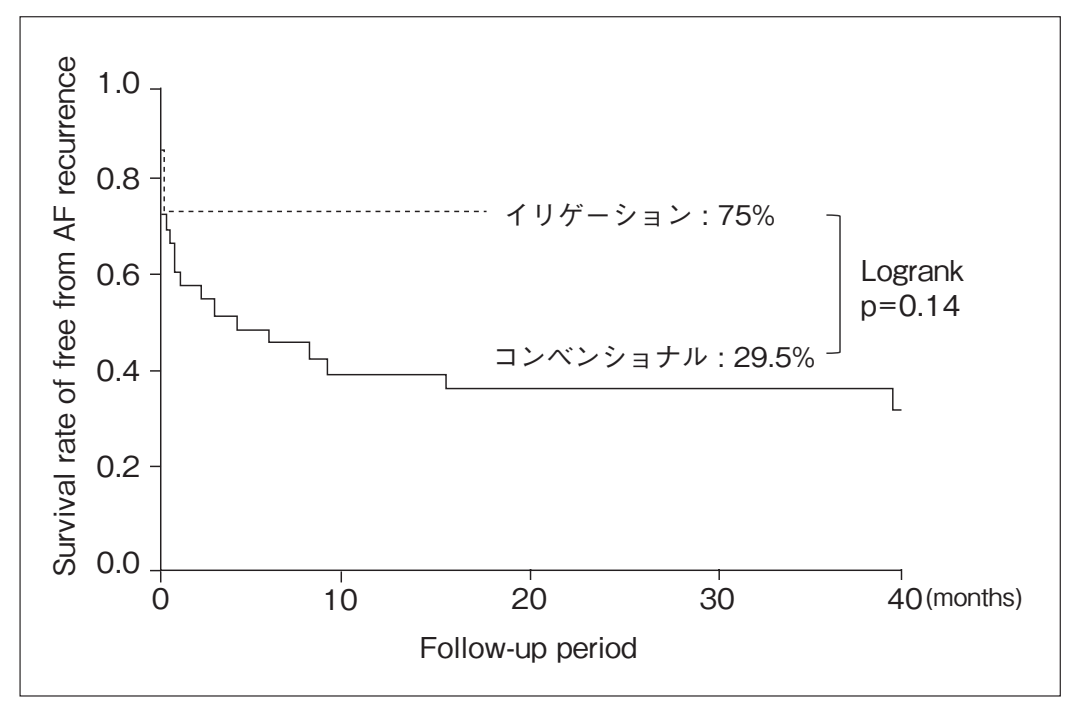

図 3

カテーテル種別による透析患者の初

回心房細動アブレーション治療成績 (Kaplan-Meier 法)

間使用については考慮する必要がある.

善することが期待される.

\section{V. まとめ}

透析患者に伴う $\mathrm{AF}$ は, 発症頻度が高い, 発症時 の臨床的影響が大きい, 薬物治療の選択肢が限られ ている，などが問題とされている，AFに対するカ テーテルアブレーションは, 非透析患者に比し初回 セッション後の $\mathrm{AF}$ 再発率が高い傾向にあり, 肺静 脈隔離を中心とした複数回の治療が必要になること が多い.イリゲーションカテーテルの登場と今後の 技術革新が，透析患者における変性心筋に対しての 通電効果を高め, AFアブレーション治療成績を改
〔文

献]

1) Genovesi S, Pogliani D, Faini A, Valsecchi MG, Riva A, Stefani F, Acquistapace I, Stella A, Bonforte G, DeVecchi A, DeCristofaro V, Buccianti G, Vincenti A : Prevalence of atrial fibrillation and associated factors in a population of long-term hemodialysis patients. Am J Kidney Dis, $2005 ; 46: 897 \sim 902$

2) Tsagalis G, Bakirtzi N, Manios E, Chouliaras I, Papagiannidou P, Stamellou E, Akrivos T, Makris F, Psimenou E, Koutroubas G, Xinos K, Vemmos K : Atrial fibrillation in chronic hemodialysis patients : prevalence, types, predictors, and treatment practices 
in Greece. Artif Organs, 2011 ; 35 : 916 922

3 ) Tokuda M, Yamane T, Matsuo S, Ito K, Narui R, Hioki M, Tanigawa S, Nakane T, Yamashita S, Inada K, Shibayama K, Miyanaga S, Yoshida H, Miyazaki H, Date T, Yokoo T, Yoshimura M : Relationship between renal function and the risk of recurrent atrial fibrillation following catheter ablation. Heart, 2011 ; $97: 137 \sim 142$

4 ) 社団法人日本透析医学会：血液透析患者における心血 管合併症の評価と治療に関するガイドライン. 2011 ; 透析会誌, 44(5)：337〜 425

5 ) Kobori A, Takahashi A, Miyazaki S, Takahashi Y,
Takei A, Kuwahara T, Miyazaki T, Kawashima T, Tamura M, Ohhigashi H, Nozato T, Hikita H, Satoh A, Aonuma K : Difficulty of Catheter Ablation for the Management of Atrial Fibrillation in Patients with Chronic Hemodialysis. Circ J, 2008 ; 72 : 455

6 ) Kobori A, Takahashi A, Tamura M, Ohhigashi H, Itoh Y, Miyazaki S, Takahashi Y, Nozato T, Kuwahara T, Hikita H, Satoh A, Aonuma K, Isobe M : Catheter Ablation for Atrial Fibrillation in Hemodialysis Patients : Evaluation of Safety, Feasibility, and Efficacy. Circ J, 2007 ; 71 : 395 